\title{
The Characteristics of Domestic Firms: Materializing Productivity Spillovers from FDI
}

\section{Seda Köymen Özer \& Selin Sayek Böke}

To cite this article: Seda Köymen Özer \& Selin Sayek Böke (2017) The Characteristics of Domestic Firms: Materializing Productivity Spillovers from FDI, Emerging Markets Finance and Trade, 53:11, 2562-2584, DOI: 10.1080/1540496X.2016.1219943

To link to this article: https://doi.org/10.1080/1540496X.2016.1219943

Accepted author version posted online: 31 Oct 2016.

Published online: 25 Sep 2017.

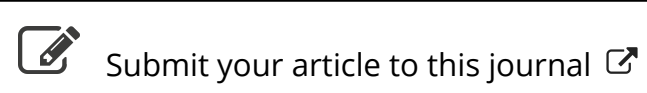

山 Article views: 74

Q View related articles $₫$

View Crossmark data $\asymp$ 


\title{
The Characteristics of Domestic Firms: Materializing Productivity Spillovers from FDI
}

\author{
Seda Köymen Özer ${ }^{1}$ and Selin Sayek Böke ${ }^{2}$ \\ ${ }^{1}$ Bilkent University, Department of Economics, Ankara, Turkey; ${ }^{2}$ The Grand National Assembly of \\ Turkey, Ankara, Turkey
}

ABSTRACT: Using detailed firm-level data from Turkey, for 1991-2001, we analyze the importance of domestic firm capabilities in allowing for productivity spillovers from foreign direct investment. The absorptive capacities we investigate are technology gap, export status, and human capital of domestic firms. The study contributes to the literature by offering an alternative measure of human capital that would be more relevant in a country where there are labor market imperfections. The results provide supporting evidence for the role played by the human capital of domestic firms, i.e., the ratio of skilled, in realizing mainly horizontal spillovers.

KEY WORDS: export status, foreign direct investment, human capital, productivity spillovers, technology gap

The transfer of new technologies and techniques plays a key role in economic growth and development of a country. This technology diffusion may take place through different channels, among which foreign direct investments (FDIs) are considered to be very important. ${ }^{1}$ Multinational companies (MNCs) operate with a higher level of technology to be able to compete with domestic firms that are familiar with the local market conditions, business practices, and consumer preferences (Blomström and Sjöholm 1999). This characteristic of MNCs enables domestic firms to gain access to new technologies through imitating the products and techniques of the foreign firms or gaining access to their managing and marketing skills, which in turn increases their productivity. Using detailed firm-level data from Turkey, this study tests whether productivity spillovers from MNCs to domestic firms depend on domestic firms' capabilities. The contribution of this study to the literature is threefold. First, it investigates the importance of domestic firms' absorptive capacities for reaping benefits from FDI through all possible channels by using various measures of firm capability. Hence, the study provides a full picture of the role of domestic firms' capacity in generating FDI spillovers through horizontal, backward, and forward channels and by separately identifying the role of each type of absorptive capacity, namely technology gap, export status, and human capital. Second, the study suggests an alternative measure of human capital that can be used as a proxy for absorptive capacity in countries that are characterized by labor market imperfections, e.g., skill mismatch. Finally, to the best of our knowledge, it is the first study that analyzes the role of domestic firms' absorptive capacities for reaping benefits from FDI in Turkey. Turkey is a large emerging market that aims to attract FDI, expecting positive productivity spillovers from superior MNCs to domestic firms. As there is evidence for serious labor market imperfections in Turkey, the country also provides an appropriate setting for testing our alternative human capital measure.

The knowledge and technology transfers occur through three types of linkages between domestic and foreign firms. The first type of interaction, labeled as horizontal linkages, can lead to spillovers where domestic firms benefit from foreign affiliates that are operating within the domestic firm's sector. The latter channel of interaction, labeled as vertical linkages, can lead to either backward or

Address correspondence to Seda Köymen Özer, Bilkent University, Department of Economics, 06800 Bilkent, Cankaya, Ankara, Turkey. E-mail: skoymen@bilkent.edu.tr or Selin Sayek Böke, The Grand National Assembly of Turkey, Ataturk Blvd No:153, 06543, Bakanliklar, Ankara, Turkey. E-mail: selin. sayekboke@tbmm.gov.tr 
forward spillovers. Backward spillovers occur when the domestic firm that operates as the input supplier to the sector that the multinational operates in benefits from this interaction. Forward spillovers occur when the multinational operates as the input supplier to the domestic firm and the domestic firm benefits from this interaction.

Earlier studies have mostly found very weak evidence regarding the existence of any positive horizontal spillovers. ${ }^{2}$ Javorcik (2004), in a seminal article, has suggested that the literature was "looking for spillovers in the wrong place." Accordingly, the findings on Lithuania reported by Javorcik (2004) document evidence supporting positive productivity spillovers through backward linkages. Following this study, a literature studying the respective roles of horizontal and vertical linkages in generating spillovers has spawned. ${ }^{3}$

Recent studies, on the other hand, have suggested different mechanisms through which FDI affects local economy through both horizontal and vertical linkages. Liu (2008) distinguishes between level and rate effects of FDI spillovers to domestic firms and shows that Chinese firms realize a loss in their productivity in the short run whereas their productivity increases in the long run. Chang and Xu (2008) analyze foreign firms' effect on local Chinese firms' survival rather than their productivity and find positive relationship between presence of foreign firms and local firms' survival probability. Zhang et al. (2010) point to the importance of foreign firms' country of origin and suggest that greater diversity of origin increases the total factor productivity (TFP) of domestic firms in China.

Finally, there is a growing literature, which our study is mostly related to, on the importance of domestic firms' absorptive capacities in realizing productivity spillovers from the presence of MNCs. In this strand of literature, the firm-level characteristics that are important for reaping potential benefits from FDI are called absorptive capacities of the firm. In this study, technological closeness of the firm to the industry leader, export status, and human capital are considered as domestic firm absorptive capacities. We test whether these domestic firm characteristics enable firms to realize potential TFP spillovers from FDI. In the next section, we discuss the absorptive capacity literature and provide a more detailed discussion of the contribution of this study.

In order to test the role played by human capital, as well as the technology gap and export status, in the realization of productivity spillovers from foreign firms, we use a plant-level data set from the Turkish manufacturing industry, covering the period 1991-2001. Upon estimation of the TFP of firms using the Levinsohn and Petrin (2003) methodology, we search for the existence of horizontal and vertical spillovers. Our results show that spillovers from horizontal channel are only experienced by Turkish firms with certain absorptive capacities, among which the human capital (the ratio of skilled job occupations in total employment) and technological closeness to industry leader play separate and significant roles. On the other hand, we do not find any evidence that being an exporter plays a role in realization of FDI spillovers. The next section reviews the relevant literature. The following section provides a discussion of the data and the variables constructed for the analysis. After that, we discuss the estimation and empirical results. The final section concludes.

\section{Literature Review}

Cohen and Levinthal (1990) define absorptive capacity of the domestic firm as "ability to recognize the value of new information, assimilate it, and apply it to commercial ends." In the studies investigating FDI spillovers, domestic firm's capabilities that enable them to learn or absorb techniques and knowledge from and compete with foreign firms have been labeled as domestic firms' absorptive capacities. ${ }^{4}$ Technology gap between domestic firm and the multinational or industry leader has been identified as a prominent absorptive capacity in the existing literature. Zhang et al. (2010) suggest that FDI spillovers are greater when the technology gap is intermediate whereas Castellani and Zanfei (2003) and Damijan et al. (2013) show that the closer the domestic firm to foreign firm, the higher the spillovers. Kokko, Tansini, and Zejan (1996); Girma and Görg (2005); Girma (2005); and Girma, Greenaway, and Wakelin (2013) suggest that the higher the magnitude of the gap, the lower the ability of domestic firm to benefit from foreign presence. 
Another absorptive capacity measure used in the literature is the exporting behavior of domestic firms. Since exporters are directly facing foreign competition, they are more accustomed to international market practices and more likely to compete with and benefit from MNCs (Barrios and Strobl 2002). Barrios and Strobl (2002); Girma (2005); Girma, Görg, and Pisu (2008); and Farole and Winkler (2015) test this hypothesis and find that FDI spillovers are larger in exporting firms compared to their domestic market-oriented counterparts. ${ }^{5}$

Recent studies consider the human capital of the firm, which is a measure that captures the skill level of workers employed by the firm, as another important domestic firm absorptive capacity. Cosar (2011) theoretically shows the essentiality of human capital for firms to augment their productivity in case of an exogenous technology shock, such as trade, FDI, and trade in ideas. There are several reasons to expect human capital to play such a role in ensuring positive spillovers via horizontal linkages. Such horizontal linkages may positively work through imitation, labor turnover, R\&D activities, and increased access to complementary business and professional services. ${ }^{6}$ On the other hand, the competition effect created by multinational entrance may prevent such direct horizontal spillovers from taking place. Multinationals competing with domestic firms may try to inhibit information leakages, impeding domestic firms' access to efficient technologies (see Javorcik 2004). Increased market shares of multinationals in the host economy may divert demand from domestic firms and increase their average costs and hence decrease their productivity (see Harrison and Aitken 1999). Firms with better human capital are expected to enjoy these positive effects while overcoming the negative competition effects.

Also, human capital may play a role as an absorptive capacity for the positive vertical spillovers. Godart and Görg (2013) show that the main channels through which the firms benefit from backward linkages, if at all, are through forcing of multinationals for reductions in costs or development of new products by these domestic firms they are linked to. The firms that are more technologically advanced and possess high levels of human capital are more able to meet these standards or can benefit from these "forced linkage effects," as termed by Godart and Görg (2013). In the forward spillovers case, the high-tech and more expensive products of foreign firms can be used as an input by domestic suppliers with higher levels of human capital. These firms may realize productivity gains through increased quality of inputs and, hence, realize higher positive forward spillovers. Thus, one can argue that the productivity spillovers from all three linkages may differ among firms with different levels of human capital. The absorptive capacity role played by the human capital level of the domestic firms has also been analyzed in other articles. ${ }^{7}$ Among these articles, Gorodnichenko, Svejnar, and Terrell (2007); Blalock and Gertler (2009); and Blalock and Simon (2009) capture human capital with education level of firm's employees, as measured by the share of university graduates in the former article and the share of high school or higher degree graduates in the latter two articles. In their analysis of FDI in 17 countries, Gorodnichenko, Svejnar, and Terrell (2007) find that human capital does not act as an absorptive capacity for any of the linkages and/or other types of economic activities. Blalock and Gertler (2009) and Blalock and Simon (2009), on the other hand, find that the firm-level human capital plays a positive absorptive capacity role in the horizontal and backward spillovers in Indonesia. Finally, Damijan et al. (2013) proxy human capital by average wage bills and find that in a majority of the countries they analyze, human capital plays an absorptive capacity role in horizontal spillovers, with less of a role for vertical spillovers.

We argue that neither education levels nor average wages fully reflect the effective use of skills in the firm. For education levels to be actually reflective of the absorptive capacity of the firms, it should be the case that the education generated skills embodied in the labor force are appropriately utilized by the firms. In other words, the job skill requirements should completely match the skill acquisition of the individuals. However, existing labor market frictions can lead to mismatches of the skills acquired and the job requirements. Such mismatches due to differential abilities across workers and jobs are discussed theoretically in several articles, including in Albrecht and Vroman (2002). Albrecht and Vroman (2002) note that a pilot can accomplish the duty of both flying a plane and delivering cabin service to passengers, though her skill acquisition would appropriately serve to fly the plane. However, 
a trained flight attendant would not be able to fly the plane but would only be able to provide service in the cabin. If a pilot is assigned as a flight attendant, or vice versa, skill mismatches would prevail in the labor market. The existence of such skill mismatches is suggestive that education-based measures of skills are not the first best measurement of the extent of available human capital of a firm. Also, the existence of on-the-job training creates continuous externalities in the labor market by increasing the skill level of workers beyond their education. Hence, a measurement of human capital that is limited with education ignores the possibility of such enhancements in skills.

The average wage also is not the first best indicator of human capital when there are imperfections in the labor market. Consider two firms, each with three job posts that include one skilled post and two unskilled posts. If in one firm there is no skill mismatch, while in the other firm one of the unskilled posts is filled by a skilled worker, then the average wage of the first firm will be lower. Therefore, even though the skill and technology content of the duties in these two firms are no different, in other words from our perspective their human capital absorptive capacities are no different, while their average wages will be different.

We argue that in a country with labor market imperfections, human capital should be measured with an alternative proxy, rather than wages and education. This alternative measure should rely on information regarding the job occupations within a firm. In the lack of education and average wage information at the firm level, previous studies measure human capital with the ratio of non-production employees to total employees as a proxy for skill ratio of the firm. However, within both production and non-production jobs, there could be both skilled and unskilled positions. Our data set includes skill information among production and non-production jobs. We have information on number of employees in each job occupation where occupations vary from worker to high-level technical personnel among production workers and office workers to managers among non-production workers. This detailed information allows us to develop a better proxy for human capital under labor market imperfections. A detailed discussion of the measurement of this alternative human capital is provided in the next section.

The extent of skill mismatches is best captured by what is labeled as over(under)-education in the literature. Over(under)-education measures the share of workers who are employed in jobs that require less (more) education than that individual's education level. A recent report CEDEFOP (2012) reveals the widespread occurrence of skill mismatches in Europe, pointing out that $30 \%$ of the population suffers from over-education and more than another $30 \%$ of the population suffers from under-education. Groot, Van, and Den Brink (2000) find that the extent of over-education in the developed countries is around 23\%. Quinn and Rubb (2006) find similar evidence for a developing country, namely Mexico. Filiztekin (2011) finds strong evidence for skill mismatches in Turkey. Filiztekin (2011) suggests that in the 1990s the extents of over-education and under-education in the Turkish labor market were $20 \%$ and $16.5 \%$, respectively. These results do point out that in any analysis as the following, where human capital is to capture an absorptive capacity, one should take into account skill mismatches. The phenomena of skill mismatches being a worldwide phenomenon, as is documented for both developed and developing countries, make this an universally relevant point. The extent of skill mismatches documented by Filiztekin (2011) for Turkey is lower than that documented for Mexico by Quinn and Rubb (2006) but higher than those documented for Portugal by Kiker, Santos, and De Oliveira (1997), rendering the Turkish case an average representative case.

In our data set, the education level of workers is not observed, but data on average wages of the firms are available. Hence, we measure human capital by using two separate measures, namely average wages and ratio of skilled jobs. The results suggest that average wages do not act as an absorptive capacity in reaping benefits from FDI presence whereas our alternative measure of human capital does. The higher the ratio of skilled jobs, the higher the TFP spillovers from FDI via horizontal channel. Hence, the results point out that in an emerging country such as Turkey, where skill mismatches are present, the ratio of skilled jobs captures the human capital level of the firm better than average wages. 


\section{Data}

The data set used in this study is on the Turkish manufacturing industry collected by the Turkish Statistical Institute (TurkStat). This data set is available at TurkStat in a machine-readable form starting from 1980. The data set covers the universe of firms that have more than 10 employees. For firms that have less than 10 employees, a sampling technique is used that changes during the period of analysis. Therefore, firms that have less than 10 employees are excluded from the analysis. The data coverage ends in $2001 .{ }^{8}$ We limit the final regression analysis to 1991-2001 since most of the variables of interest became available in $1990 .^{9}$ This time coverage is much larger compared to previous studies and is long enough to record changes in foreign ownership of individual firms and overall macroeconomic conditions. ${ }^{10}$ Although the Statistical Institute collects information for all firms, regardless of their employment size, in this study, we focus only on firms with 25 or more employees simply due to the unavailability of several of the necessary variables or the firms that have 10-24 employees. ${ }^{11}$ Finally, this study excludes public firms since during the period of analysis, these firms in Turkey were running huge losses as they are not profit maximizing or cost minimizing firms. Hence, the productivity is not a priority for public firms, which makes them outlier in the following analysis.

Total number of firms and foreign affiliated firms included in this analysis are 5578 and 265, respectively. Table 1 presents the number of firms and foreign affiliated firms for each year in the analysis. Although the absolute number of firms and foreign firms has increased throughout the period of this study, the percentage share of foreign affiliated plants has only increased from $4.7 \%$ in 1992 to $5.7 \%$ in 2001 .

Our goal is to test for the relationship between multinationals and domestic firm productivity, and whether this relationship differs for local firms with differential human capital characteristics. For this purpose, we need to calculate the TFP level for each firm and regress this productivity on industrybased linkage measures and their interaction with a firm-level human capital absorptive capacity indicator.

The TFP for each firm is calculated using both OLS and the Levinsohn-Petrin methodology, for every sector. The measures from Levinsohn-Petrin calculation are used. Table 2 provides basic summary statistics across three-digit sectors. Industries show variation in foreign presence, output, employment, and capital to labor ratios. The variables are statistically different among sectors. ${ }^{12}$ These differences are important in the calculation of TFP. Since sectors differ in these production-related measures, it makes more sense to calculate the TFP sector by sector, rather than using the whole sample.

Table 3 presents summary statistics for the firm characteristics for each year. It is evident that the foreign firms are larger in terms of production and number of employees and are more capital intensive when one compares average employment and average capital/labor with their domestic counterparts. Furthermore, average total factor productivity of foreign-owned firms is much higher than domestically owned firms. Finally, foreign firms employ more skilled labor than their domestic counterparts supporting the evidence that multinationals are more technologically advanced and require more

Table 1. Summary statistics-domestic vs. foreign plants.

\begin{tabular}{lccccccccccc}
\hline & 1991 & $\mathbf{1 9 9 2}$ & $\mathbf{1 9 9 3}$ & $\mathbf{1 9 9 4}$ & $\mathbf{1 9 9 5}$ & $\mathbf{1 9 9 6}$ & $\mathbf{1 9 9 7}$ & $\mathbf{1 9 9 8}$ & $\mathbf{1 9 9 9}$ & $\mathbf{2 0 0 0}$ & $\mathbf{2 0 0 1}$ \\
\hline Total number of plants & 2494 & 2498 & 2811 & 3095 & 3322 & 3450 & 3606 & 3862 & 4025 & 4022 & 3976 \\
Number of FA plants & 125 & 135 & 159 & 173 & 190 & 185 & 190 & 221 & 242 & 241 & 255 \\
Percentage of FA plants & 5.0 & 5.4 & 5.6 & 5.6 & 5.7 & 5.3 & 5.3 & 5.7 & 6.0 & 6.0 & 6.4
\end{tabular}

Notes: Data is obtained from TurkStat. Plants with $10 \%$ or more foreign ownership shares are defined as foreign affiliated (FA) plants. 
Table 2. Summary statistics-sector based.

\begin{tabular}{lccccccc}
\hline Sector & All plants-years & FA plants-years & \% of FA plants & Avg. output & Average emp. & Avg. K/L & Avg. TFP \\
\hline & 1 & 2 & 3 & 4 & 5 & 6 & 7 \\
311 & 3495 & 182 & 5.2 & 35.5 & 149 & 120.0 & 3.6 \\
312 & 951 & 93 & 9.8 & 28.5 & 99 & 91.9 & 3.1 \\
313 & 324 & 21 & 6.5 & 53.5 & 151 & 279.0 & 4.7 \\
321 & 6781 & 132 & 2.0 & 43.5 & 250 & 158.1 & 6.0 \\
322 & 4145 & 128 & 3.1 & 20.0 & 142 & 47.4 & 6.1 \\
323 & 330 & 1 & 0.3 & 24.4 & 77 & 69.3 & 5.2 \\
324 & 354 & 3 & 0.8 & 11.7 & 95 & 42.2 & 2.3 \\
332 & 488 & 0 & 0 & 18.9 & 139 & 94.0 & 4.8 \\
341 & 713 & 56 & 7.8 & 42.4 & 128 & 135.9 & 4.7 \\
342 & 657 & 11 & 1.7 & 11.7 & 93 & 446.7 & 4.5 \\
352 & 1314 & 258 & 19.6 & 78.5 & 187 & 176.5 & 6.8 \\
355 & 640 & 61 & 9.5 & 42.0 & 162 & 83.2 & 6.1 \\
356 & 1622 & 87 & 5.4 & 34.6 & 100 & 146.0 & 6.2 \\
361 & 225 & 7 & 3.1 & 107.9 & 406 & 161.5 & 5.2 \\
362 & 319 & 20 & 6.3 & 100.5 & 324 & 172.1 & 4.8 \\
369 & 2525 & 106 & 4.2 & 27.2 & 105 & 161.2 & 4.1 \\
371 & 1151 & 52 & 4.5 & 102.7 & 181 & 125.8 & 7.0 \\
372 & 532 & 8 & 1.5 & 51.7 & 103 & 157.1 & 3.5 \\
381 & 3143 & 150 & 4.7 & 27.8 & 101 & 198.7 & 6.6 \\
382 & 2516 & 146 & 5.8 & 38.7 & 128 & 98.5 & 5.5 \\
383 & 2006 & 263 & 18.1 & 117.4 & 194 & 113.9 & 5.4 \\
384 & 2062 & 271 & 13.1 & 101.9 & 272 & 99.5 & 5.6 \\
385 & 353 & 33 & 9.3 & 20.5 & 91 & 79.4 & 3.7 \\
390 & 475 & 27 & 5.7 & 11.5 & 99 & 74.2 & 3.1
\end{tabular}

Notes: Data is obtained from TurkStat. Plants with $10 \%$ or more foreign ownership shares are defined as foreign affiliated (FA) plants. Output measure is in billions and both output and $(K / L)$ ratio is measured in 1990 prices. Total factor productivity (TFP) is calculated using the Levinsohn-Petrin estimation procedure. The sectors are as follows: 311 Food, 312 Food Miscellaneous, 313 Beverages, 321 Textiles, 322 Wearing Appeal, 323 Leather Products, 324 Footwear, 332 Furniture, 341 Paper, 342 Printing, 352 Other Chemicals, 355 Rubber Products, 356 Plastics, 361 Ceramics, 362 Glass, 369 Nonmetal Minerals, 371 Basic Metal, 372 Nonferrous Metals, 381 Fabricated Metals, 382 Non-electrical Mach., 383 Electrical Machinery, 384 Transport Equipment, 385 Professional Equipment, 390 Other Manufacturing Products.

skilled labor. All of these differences between domestic and foreign firms are statistically significant, pointing to the possibility of productivity spillovers from these more advanced foreign firms to the less productive domestic firms. We discuss the details of TFP calculation in the Appendix. Tables 4 and 5 show the estimation results of the production function using OLS and Levinsohn-Petrin, respectively.

FDI indicators, namely the horizontal, forward, and backward linkages, are measured in the traditional approach. ${ }^{13}$ In Table 6 , the summary statistics for the linkage measures are presented..$^{14}$ Here, one can see that although not significantly, the averages of the three linkages have increased throughout the period, allowing for spillovers. Table 7 presents pair-wise correlations between variables. The correlation coefficients of all three linkage variables are found to be low and insignificant. The correlation between the horizontal and backward linkages is -0.04 , the correlation between the horizontal and forward linkages is 0.21 , and the correlation between the two vertical linkage measures is -0.03 . These low correlations suggest that a multicollinearity is not a concern, and all linkage measures simultaneously can be included in the analysis. 
Table 3. Summary statistics-yearly.

\begin{tabular}{lrrrrrrrrrrr}
\hline & 1991 & 1992 & 1993 & 1994 & 1995 & 1996 & 1997 & $\mathbf{1 9 9 8}$ & $\mathbf{1 9 9 9}$ & $\mathbf{2 0 0 0}$ & $\mathbf{2 0 0 1}$ \\
\hline All plants & & & & & & & & & & & \\
Avg. emp. & 185 & 176 & 167 & 151 & 155 & 166 & 172 & 172 & 159 & 163 & 158 \\
Avg. skill (\%) & 17.3 & 18.0 & 17.5 & 19 & 18.2 & 17.7 & 17.3 & 17.7 & 18.3 & 18.0 & 19.2 \\
Avg. output & 38.0 & 44.0 & 47.7 & 40.5 & 44.4 & 43.4 & 50.2 & 47.0 & 45.3 & 50.6 & 48.6 \\
Avg. K/L & 91.4 & 93.0 & 119.2 & 126.2 & 150.9 & 140.8 & 141.7 & 126.8 & 143.4 & 146.5 & 156.9 \\
Avg. TFP & 5.2 & 5.3 & 5.4 & 5.3 & 5.3 & 5.3 & 5.4 & 5.5 & 5.5 & 5.5 & 5.4 \\
FA plants & & & & & & & & & & & \\
Avg. emp. & 589 & 546 & 499 & 451 & 418 & 425 & 423 & 413 & 380 & 393 & 393 \\
Avg. skill (\%) & 17.7 & 19.4 & 20.0 & 21.2 & 21.2 & 21.0 & 21.0 & 20.0 & 20.1 & 21.0 & 21.0 \\
Avg. output & 187.9 & 227.3 & 255.5 & 197.1 & 215.9 & 212.4 & 254.3 & 226.8 & 211.9 & 247.8 & 234.2 \\
Avg. K/L & 140.4 & 145.1 & 144.0 & 162.1 & 165.8 & 175.1 & 181.1 & 187.5 & 217.1 & 225.0 & 244.2 \\
Avg. TFP & 5.8 & 5.9 & 6.2 & 5.9 & 6.0 & 5.9 & 6.0 & 6.0 & 6.0 & 6.1 & 6.1 \\
Local plants & & & & & & & & & & & \\
Avg. emp. & 164 & 155 & 147 & 133 & 139 & 151 & 158 & 157 & 145 & 148 & 142 \\
Avg. skill (\%) & 17.3 & 17.9 & 17.3 & 18.8 & 18.0 & 17.6 & 17.1 & 17.6 & 18.1 & 17.8 & 19.1 \\
Avg. output & 30.0 & 33.4 & 35.2 & 31.2 & 34.0 & 33.8 & 38.8 & 36.1 & 34.7 & 38.1 & 35.8 \\
Avg. K/L & 88.8 & 90.0 & 117.7 & 124.1 & 150.0 & 138.9 & 139.6 & 123.0 & 138.8 & 141.4 & 151.0 \\
Avg. TFP & 5.1 & 5.3 & 5.4 & 5.2 & 5.3 & 5.2 & 5.4 & 5.4 & 5.4 & 5.4 & 5.4 \\
& & & & & & & & & & &
\end{tabular}

Notes: Data is obtained from TurkStat. Plants with $10 \%$ or more foreign ownership shares are defined as foreign affiliated (FA) plants. Output measure is in billions and both output and $(K / L)$ ratio is measured in 1990 prices. Skill is the percentage of high- and middle-level technical personnel, management staff, and foremen in total employment. Total factor productivity (TFP) is calculated using the Levinsohn-Petrin estimation procedure.

We also include sectoral control variables. Following Javorcik (2004), we try to distinguish the technological spillovers from benefits of scale by controlling for a variable that is defined as the demand of other sectors for sector $j$ 's products, which is calculated as:

$$
\text { Demand }_{j t}=\sum_{m} a_{j m} Y_{m t}
$$

where $a_{j m}$ is the Input-Output matrix coefficient indicating that in order to produce one unit of good $\mathrm{m}$ $a_{j m}$ units of sector $j$ 's goods are needed and $Y_{m t}$ is the output of sector $m$ at time $t$, deflated by threedigit sectoral price deflator. Furthermore, to be able to distinguish the competition effect from technological spillovers, we use the herfindahl index as an additional regressor. The herfindahl index for sector $j$ gives the industry concentration that takes smaller values if the industry is competitive.

\section{Measurement of Absorptive Capacities}

As it is discussed above, there are three absorptive capacity measures that are used in the spillover analysis: the human capital, technology gap, and export status. First, to be consistent with the previous literature, we report the absorptive capacity results by taking average wage of the firm as a proxy of human capital.

$$
\text { hcap }_{i j t}^{1}=\text { average } \text { wage }_{i j t}
$$

for firm $i$ in sector $j$ at time $t$.

Our alternative human capital measure is defined as the share of skilled job occupations in total job occupations: 
Table 4. OLS estimates of production function (1991-2001).

\begin{tabular}{|c|c|c|c|c|c|c|c|c|}
\hline & Sector & Unskilled*** & S.E. & Skilled & S.E. & Capital & S.E. & No of Obs. \\
\hline \multicolumn{9}{|c|}{ Dependent variable: value added } \\
\hline 311 & Food & 0.67 & 0.04 & $0.30 * * *$ & 0.04 & $0.23 * * *$ & 0.03 & 1710 \\
\hline 312 & Food miscellaneous & 0.90 & 0.13 & $0.38 * * *$ & 0.10 & 0.07 & 0.07 & 460 \\
\hline 313 & Beverages & 0.87 & 0.22 & 0.14 & 0.11 & $0.36 * * *$ & 0.10 & 164 \\
\hline 321 & Textiles & 0.75 & 0.03 & $0.25^{* * *}$ & 0.02 & $0.19 * * *$ & 0.02 & 3787 \\
\hline 322 & Wearing appeal & 0.72 & 0.05 & $0.20 * * *$ & 0.04 & $0.19 * * *$ & 0.03 & 1685 \\
\hline 323 & Leather products & 1.26 & 0.18 & 0.18 & 0.15 & -0.01 & 0.09 & 145 \\
\hline 324 & Footwear & 0.91 & 0.09 & $0.44 * * *$ & 0.09 & 0.06 & 0.05 & 150 \\
\hline 332 & Furniture & 0.96 & 0.09 & $0.14^{* *}$ & 0.07 & $0.24 * * *$ & 0.07 & 282 \\
\hline 341 & Paper & 0.86 & 0.12 & 0.07 & 0.05 & $0.33^{* * *}$ & 0.05 & 367 \\
\hline 342 & Printing \& publishing & 0.94 & 0.13 & 0.12 & 0.09 & $0.09 *$ & 0.05 & 275 \\
\hline 352 & Other chemicals & 0.71 & 0.04 & $0.30 * * *$ & 0.06 & $0.28 * * *$ & 0.04 & 1014 \\
\hline 355 & Rubber products & 0.58 & 0.07 & $0.29 * * *$ & 0.06 & $0.38 * * *$ & 0.07 & 473 \\
\hline 356 & Plastics & 0.54 & 0.09 & $0.34 * * *$ & 0.06 & $0.29 * * *$ & 0.05 & 853 \\
\hline 361 & Ceramics & 0.86 & 0.10 & -0.00 & 0.10 & $0.47 * * *$ & 0.08 & 152 \\
\hline 362 & Glass & 0.90 & 0.12 & 0.07 & 0.07 & $0.32 * * *$ & 0.06 & 239 \\
\hline 369 & Nonmetal minerals & 0.65 & 0.07 & $0.58 * * *$ & 0.07 & $0.29 * * *$ & 0.04 & 1184 \\
\hline 371 & Iron \& steel & 0.88 & 0.09 & $0.20 * * *$ & 0.07 & $0.29 * * *$ & 0.05 & 658 \\
\hline 372 & Nonferrous metals & 1.14 & 0.13 & $0.14^{*}$ & 0.07 & $0.16 * *$ & 0.07 & 249 \\
\hline 381 & Fabricated metals & 0.76 & 0.06 & $0.29 * * *$ & 0.06 & $0.24 * * *$ & 0.03 & 1707 \\
\hline 382 & Non-electrical mach. & 0.80 & 0.07 & $0.33^{* * *}$ & 0.05 & $0.12 * * *$ & 0.02 & 1492 \\
\hline 383 & Electrical machinery & 0.68 & 0.06 & $0.37 * * *$ & 0.05 & $0.24 * * *$ & 0.03 & 1373 \\
\hline 384 & Transport equipment & 0.89 & 0.06 & $0.17 * * *$ & 0.05 & $0.23 * * *$ & 0.03 & 1304 \\
\hline 385 & Professional equipment & 1.05 & 0.13 & 0.07 & 0.07 & $0.20 * * *$ & 0.07 & 247 \\
\hline 390 & Other manufacturing products & 0.62 & 0.17 & $0.33^{* *}$ & 0.15 & $0.25 * * *$ & 0.06 & 274 \\
\hline
\end{tabular}

Notes: S. E. denotes standard errors. $* * *, * *$, and * indicate the statistical significance at the $1 \%, 5 \%$, and $10 \%$ levels, respectively. Statistical significance indicators apply to all sectors if it is next to the variable name.

$$
\text { hcap }_{i j t}^{2}=\frac{\text { Skilled production and non-production } \text { employees }_{i j t}}{\text { Total } \text { employees }_{i j t}}
$$

The data provides the information about the characteristics of labor's job occupations enlisted in Table 8. Using the information on job occupations within firms, two alternative classifications are developed to capture the extent of skill composition of duties in a firm. In the first classification, we take a narrow definition of skilled jobs and only include high-level technical personnel and management staff as skilled positions. In the second classification, we broaden this concept and also include positions where on-the-job learning and experience could create skills. By doing so, the second classification adds middle technical personnel and foremen to the first one. We take the view that skills are inherent in both production and nonproduction jobs. The summary statistics of these two measures are provided in Table 6 . The analysis is conducted using both classifications, and since the results are qualitatively and quantitatively the same, in the remainder of the article, the results of regressions using the broad definition of human capital are reported due to limited space.

Following literature, we define technology gap as the ratio of total factor productivity of domestic firm to total factor productivity of the industry leader ${ }^{15}$ :

$$
t c_{i j t}=\ln \left(\frac{T F P_{i j t}}{\max \quad \text { industry }\left(T F P_{j t}\right)}\right)
$$


Table 5. Levinsohn-Petrin estimates of production function (1991-2001).

\begin{tabular}{|c|c|c|c|c|c|c|c|c|}
\hline \multicolumn{2}{|c|}{ Sector } & \multirow[t]{2}{*}{ Unskilled $^{* * *}$} & \multirow[t]{2}{*}{ S.E. } & \multirow[t]{2}{*}{ Skilled } & \multirow[t]{2}{*}{ S.E. } & \multirow[t]{2}{*}{ Capital } & \multirow[t]{2}{*}{ S.E. } & \multirow[t]{2}{*}{ No of Obs. } \\
\hline Depen & dent variable: value added & & & & & & & \\
\hline 311 & Food & 0.45 & 0.05 & $0.24^{* * *}$ & 0.03 & $0.43^{* * *}$ & 0.06 & 1710 \\
\hline 312 & Food Miscellaneous & 0.54 & 0.08 & $0.25^{* * *}$ & 0.08 & $0.47^{* * *}$ & 0.17 & 460 \\
\hline 313 & Beverages & 0.83 & 0.24 & 0.09 & 0.10 & 0.21 & 0.25 & 164 \\
\hline 321 & Textiles & 0.55 & 0.04 & $0.20 * * *$ & 0.03 & $0.17 * * *$ & 0.03 & 3785 \\
\hline 322 & Wearing appeal & 0.56 & 0.04 & $0.15^{* * *}$ & 0.03 & $0.14^{* *}$ & 0.07 & 1684 \\
\hline 323 & Leather products & 0.85 & 0.20 & 0.11 & 0.13 & 0.18 & 0.22 & 145 \\
\hline 324 & Footwear & 0.86 & 0.15 & $0.40^{* * *}$ & 0.11 & $0.38^{* *}$ & 0.20 & 150 \\
\hline 332 & Furniture & 0.66 & 0.11 & $0.15^{*}$ & 0.08 & $0.22^{*}$ & 0.12 & 282 \\
\hline 341 & Paper & 0.84 & 0.14 & 0.07 & 0.06 & 0.22 & 0.15 & 366 \\
\hline 342 & Printing \& publishing & 0.72 & 0.14 & $0.10^{*}$ & 0.05 & $0.21 *$ & 0.12 & 275 \\
\hline 352 & Other chemicals & 0.47 & 0.09 & $0.23^{* * *}$ & 0.05 & $0.18^{*}$ & 0.09 & 1013 \\
\hline 355 & Rubber products & 0.26 & 0.12 & $0.22^{* * *}$ & 0.06 & $0.24^{* * *}$ & 0.09 & 473 \\
\hline 356 & Plastics & 0.33 & 0.09 & $0.25^{* * *}$ & 0.06 & $0.27 * * *$ & 0.07 & 853 \\
\hline 361 & Ceramics & 0.51 & 0.15 & 0.04 & 0.07 & 0.32 & 0.21 & 151 \\
\hline 362 & Glass & 0.83 & 0.14 & 0.09 & 0.08 & 0.22 & 0.20 & 239 \\
\hline 369 & Nonmetal minerals & 0.56 & 0.06 & $0.29^{* * *}$ & 0.04 & $0.32^{* *}$ & 0.14 & 1184 \\
\hline 371 & Iron \& steel & 0.64 & 0.09 & $0.19 * * *$ & 0.06 & 0.06 & 0.10 & 658 \\
\hline 372 & Nonferrous metals & 0.86 & 0.12 & 0.00 & 0.07 & $0.34 * *$ & 0.16 & 249 \\
\hline 381 & Fabricated metals & 0.47 & 0.07 & $0.18^{* * *}$ & 0.04 & $0.17 * * *$ & 0.05 & 1707 \\
\hline 382 & Non-electrical mach. & 0.57 & 0.07 & $0.25^{* * *}$ & 0.04 & $0.21 * * *$ & 0.08 & 1492 \\
\hline 383 & Electrical machinery & 0.45 & 0.07 & $0.28^{* * *}$ & 0.04 & $0.32 * * *$ & 0.08 & 1373 \\
\hline 384 & Transport equipment & 0.64 & 0.08 & $0.12^{* * *}$ & 0.04 & $0.20 *$ & 0.11 & 1304 \\
\hline 385 & Professional equipment & 0.99 & 0.21 & 0.06 & 0.08 & 0.26 & 0.19 & 247 \\
\hline 390 & Other manufacturing Products & 0.50 & 0.18 & $0.29 * * *$ & 0.10 & $0.45^{* * *}$ & 0.20 & 274 \\
\hline
\end{tabular}

Notes: S. E. denotes standard errors. ***,**, and * indicates the statistical significance at the $1 \%, 5 \%$, and $10 \%$ levels, respectively. Statistical significance indicators apply to all sectors if it is next to the variable name.

From now on, we prefer to rename this measure as "Technological closeness (TC)" since by construction, the higher the $t c_{i j t}$, the closer the domestic firm to the industry leader.

For exporting status of the firm, we create a dummy variable, $\exp _{i j t}$, that takes the value 1 if the firm is exporting and 0 otherwise. The exporter firms are those that have exported at least 1 year, and all other firms are classified in the latter group. ${ }^{16}$ Table 6 shows the rate of exporting firms as a percentage of total firms for the period of the analysis.

\section{Empirical Analysis}

\section{FDI Spillover Results}

The statistics provided in Table 3 point to a statistically significant positive difference between the productivity of foreign and domestic firms. We also run a regression to test for this and find that this is valid with a lag and is prominent for foreign firms with larger share of foreign ownership. Hence these findings point to us that it is relevant to study whether these more productive foreign firms do create productivity spillovers to local firms. ${ }^{17}$

The literature tests for the existence of these spillovers by regressing a measure of productivity on the measures of linkages, as defined above. Following Schoors and Tol (2002); Blalock and Gertler (2009); Blalock and Simon (2009); Taymaz and Yilmaz (2008); we start by estimating the following regression for only the domestic firms: 


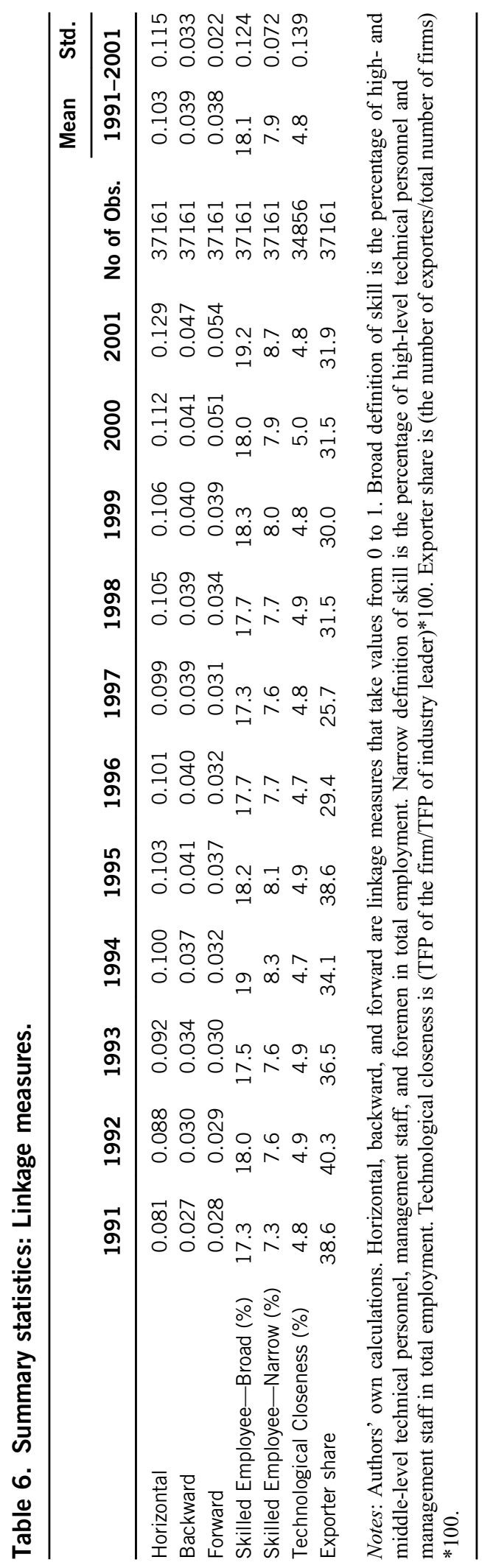


Table 7. Full correlation matrix.

\begin{tabular}{|c|c|c|c|c|c|c|c|c|}
\hline & & & & & & Skilled & Tech. & Export \\
\hline & Horizontal & Backward & Forward & Demand & Herfindahl & Emp. & Closeness & Stat. \\
\hline Horizontal & 1.00 & & & & & & & \\
\hline Backward & -0.04 & 1.00 & & & & & & \\
\hline Forward & 0.21 & -0.03 & 1.00 & & & & & \\
\hline Demand & -0.07 & -0.01 & -0.13 & 1.00 & & & & \\
\hline Herfindahl & 0.42 & -0.12 & 0.23 & -0.37 & 1.00 & & & \\
\hline Skilled employee & 0.13 & 0.04 & 0.08 & -0.04 & 0.10 & 1.00 & & \\
\hline Technological closeness & 0.11 & -0.04 & 0.13 & -0.05 & 0.23 & 0.04 & 1.00 & \\
\hline Export status & -0.02 & -0.02 & -0.04 & -0.03 & -0.00 & -0.01 & 0.13 & 1.00 \\
\hline
\end{tabular}

Table 8. Occupations.

\begin{tabular}{l} 
A. Production workers \\
\hline 1. Technical personnel \\
a) High-level technical personnel \\
b) Medium-level technical personnel \\
2. Foremen \\
3. Workers \\
B. Management and office workers \\
1. Management personnel \\
2. Office personnel \\
3. Other \\
Notes: Classifications are obtained \\
from manufacturing survey of \\
TurkStat.
\end{tabular}

$$
\begin{gathered}
\operatorname{lnTFP}_{i j, t}=\beta_{0}+\beta_{1} \text { horizontal }_{j, t-1}+\beta_{2} \text { backward }_{j, t-1}+\beta_{3} \text { forward }_{j, t-1} \\
+ \text { control variables }+\alpha_{i}+\alpha_{t}+\varepsilon_{i j, t}
\end{gathered}
$$

where $\operatorname{lnTFP} i j t$ is natural logarithm of total factor productivity of firm $i$, operating in sector $j$, at time $t$. Horizontal $_{j, t-1}$, backward $_{j, t-1}$, and forward $_{j, t-1}$ are linkage measures for industry $j$ where firm $i$ operates in, and $\alpha_{i}$ and $\alpha_{t}$ are firm and year fixed effects, respectively. ${ }^{18}$ Since our FDI linkage measures, namely horizontal, backward, and forward, are at the sectoral level, we do not include sector-year fixed effects. Hence, we control for sectoral characteristics with above defined measures, i.e., "herfindahl" and "demand."

The results for the regressions are presented in Table 9. On the premise that it takes time for the spillovers to accrue all linkage measures are one-period lagged. This lag structure also allows for a way of dealing with possible endogeneities between linkages and TFP. Our results suggest no significant spillovers from any channels, except for the finding that forward linkages are negatively associated with the level of TFP. Such negative association between TFP and forward spillovers is similar to the findings presented in Javorcik (2004), who suggests that the negative association could be explained as follows: After acquiring domestic firms in supplying sectors, foreign owners may upgrade their production techniques and start to produce higher-quality inputs that are sold at higher prices. Therefore, domestic firms may get hurt by the increasing cost. Moreover, only high technology 
Table 9. Spillovers from FDI.

\begin{tabular}{|c|c|c|c|c|c|c|}
\hline & 1 & 2 & 3 & 4 & 5 & 6 \\
\hline \multicolumn{7}{|l|}{ Variable } \\
\hline horizontal(t-1) & $\begin{array}{c}0.05 \\
(0.44)\end{array}$ & $\begin{array}{c}0.02 \\
(0.43)\end{array}$ & & & $\begin{array}{c}0.03 \\
(0.43)\end{array}$ & $\begin{array}{c}0.01 \\
(0.43)\end{array}$ \\
\hline backward(t-1) & & & $\begin{array}{c}0.43 \\
(0.66)\end{array}$ & $\begin{array}{c}0.48 \\
(0.69)\end{array}$ & $\begin{array}{c}0.43 \\
(0.66)\end{array}$ & $\begin{array}{c}0.48 \\
(0.69)\end{array}$ \\
\hline forward(t-1) & & & $\begin{array}{c}-0.70^{*} \\
(0.36)\end{array}$ & $\begin{array}{c}-0.63^{*} \\
(0.35)\end{array}$ & $\begin{array}{c}-0.69^{*} \\
(0.36)\end{array}$ & $\begin{array}{c}-0.63^{*} \\
(0.35)\end{array}$ \\
\hline Herfindahl & & $\begin{array}{c}-0.74 \\
(0.68)\end{array}$ & & $\begin{array}{c}-0.77 \\
(0.70)\end{array}$ & & $\begin{array}{c}-0.77 \\
(0.70)\end{array}$ \\
\hline Demand & & $\begin{array}{c}0.02 \\
(0.02)\end{array}$ & & $\begin{array}{c}0.02 \\
(0.02)\end{array}$ & & $\begin{array}{c}0.02 \\
(0.02)\end{array}$ \\
\hline Sectoral Controls & No & Yes & No & Yes & No & Yes \\
\hline Observations & 29,518 & 29,518 & 29,518 & 29,518 & 29,518 & 29,518 \\
\hline R-squared & 0.014 & 0.014 & 0.014 & 0.014 & 0.014 & 0.012 \\
\hline \multicolumn{7}{|c|}{$\begin{array}{l}\text { Notes: The numbers in parenthesis denote standard errors. } * * *, * * \text {, and } * \text { indicate the statistical significance at the } 1 \% \text {, } \\
5 \% \text {, and } 10 \% \text { levels, respectively. Sample includes data from } 1991 \text { to } 2001 \text {. The dependent variable is } \ln (\mathrm{TFP}) \text {. } \\
\text { Horizontal, backward, and forward are sectoral linkage measures that take values from } 0 \text { to } 1 \text {. Sectoral controls are } \\
\text { "demand" that is the amount of output of the sector that is used by other sectors and "herfindahl" that is the usual } \\
\text { herfindahl index. All columns report regressions estimated by fixed effect OLS. }\end{array}$} \\
\hline
\end{tabular}

firms might be capable of utilizing these higher-quality and more expensive inputs produced by MNCs. Another interpretation is that some firms, whose characteristics we are yet unable to observe at this stage of the analysis, may prevent them from reorganizing their production schedules upon the increased linkages in the economy and experience a loss of efficiency.

To provide a possible explanation for statistically insignificant horizontal and backward spillovers, and negative and significant forward spillovers, we take a deeper investigation by taking firm capabilities into consideration.

\section{Absorptive Capacity Results}

We next study our main hypothesis, that is, the absorptive capacity role played by technological capacity, human capital, and export status of the domestic firm. We define the three absorptive capacities $(\mathrm{ABC})$ as follows: ${ }^{19}$

$$
A B C_{i j, t}=h_{c a p} p_{i j, t-1} \text { or } A B C_{i j, t}=t c_{i j, t-1} \text { or } A B C_{i j, t}=\exp _{i j, t-1} .
$$

We include absorptive capacities and their interactive terms in Equation 1 and estimate the following equation:

$$
\begin{aligned}
& \operatorname{lnTFP}_{i j, t}=\beta_{0}+\beta_{1} \text { linkage }_{j, t-1}+\beta_{2} \text { linkage }_{j, t-1}{ }^{*} A B C_{i j, t-1} \\
& +\beta_{3}{ }^{*} A B C_{i j, t-1}+\text { sectoral control variables }+\alpha_{i}+\alpha_{t}+\varepsilon_{i j, t}
\end{aligned}
$$

where linkage measures are horizontal, backward, and forward and $A B C$ measures are average wage $(a w)$, the ratio of skilled jobs in total employment $(s j)$, technological closeness $(t c)$, and export status $(\exp )$.

Before proceeding with the estimation, it is important to note the concern of possible endogeneities the analysis could be ridden with. There are two possible dimensions of endogeneity that could be relevant for this analysis. The first concern is that the linkage measures (horizontal, forward, backward) could be dependent on the domestic firm TFP, due to the incentive of multinationals in investing 
in sectors where they can reap the benefits of high productivity of domestic firms. We utilize two alternative solutions: using sector-year fixed effects and/or introducing a lag structure. We implement both solutions. The former solution has been used in the firm-level study conducted by Fons-Rosen et al. (2013), making use of several countries in the analysis. Given the single-country focus in our analysis, the inclusion of a sector-year fixed effect makes it impossible to include the linkage measures that are sectoral variables with time dimension. In other words, when we include sector-year fixed effects, our linkage measures drop out of regressions. Only the interaction term and absorptive capacity itself can be interpreted in these regressions. Since we find that inclusion of sector-year fixed effects does not change our results neither quantitatively nor qualitatively, we do not present sector-year fixed effect regressions due to lack of space.

The second possible source of endogeneity is among the productivity of firms and their human capital structures. We implement two possible solutions. First, in implementing the LP methodology, we include the unskilled and skilled labor individually, eliminating their direct effects on the productivity of the firms. Second, we appropriately lag the human capital indicators.

Also there might be a simultaneity between human capital and foreign presence: The domestic firm may realize a productivity increase from foreign presence because it possesses higher level of human capital or the domestic firm may hire more high skilled labor after realizing the productivity increase from multinationals. ${ }^{20}$ To avoid this problem, the human capital variable should be lagged one more period than foreign presence variable. Note that, since foreign presence measure is already one-period lagged, this implies two-period lagged values of human capital to be utilized in the analysis.

Following Damijan et al. (2013), we start by testing for the role of absorptive capacities measuring the human capital using average wages paid by the firms. ${ }^{21}$ The results are reported in the left panel of Table 10 in columns 1 through 4 . In contrast to the results of Damijan et al. (2013), they point out the insignificance of human capital as an absorptive capacity when measured by average wages. As we point out while we review the literature, the insignificance of average wages as an absorptive capacity may be explained as follows. The average wages across two firms would differ with the extent of skill mismatch across these firms. In other words, if in one firm unskilled jobs are filled with skilled workers, whereas in another firm unskilled workers and jobs are properly matched, the wages will be higher in the former one. In this case, although the skill and technology content of the duties between firms do not differ, the average wages will be different across firms. Hence, we argue that the average wages may not capture any information about human capital level of the firm in a country with skill mismatch in the labor market. The results of Filiztekin (2011) suggest that skill mismatch is an important problem of Turkish labor market. Hence, we hypothesize that the ratio of skilled jobs serves as a better proxy for human capital since it gives information on skill content of the duties.

The results for the regressions using the ratio of skilled job occupations in total occupations as the human capital absorptive capacity are reported in the right panel of Table 10. Column (5) suggests that the horizontal spillovers themselves remain insignificant with a negative sign. The interaction of horizontal linkages with the skill composition measure is statistically significant. ${ }^{22}$ The positive sign and statistical significance of the interaction term reflects the view that domestic firms that have higher levels of human capital realize increases in TFP from a rise in foreign presence in their sector. In other words, only local firms that have the skill composition to allow them to imitate or compete with the MNCs are able to positively and significantly benefit more from the horizontal linkages with the MNCs. The individual horizontal term and the interactive term are jointly statistically significant. Overall, these results strengthen our understanding of the role played by human capital in ensuring productivity spillovers from MNCs. ${ }^{23}$

While average wages do not play any significant role as an absorptive capacity, the ratio of skilled jobs has a positive impact in realization of TFP spillovers from FDI. This is consistent with our expectations that in the presence of labor market imperfections such as skill mismatch, our alternative measure serves as a better proxy of human capital level of the domestic firm.

The absorptive capacity analysis is repeated for vertical spillovers, and results are reported in columns (6) and (7) of Table 10. The effects of vertical linkages are found to be insignificant and 


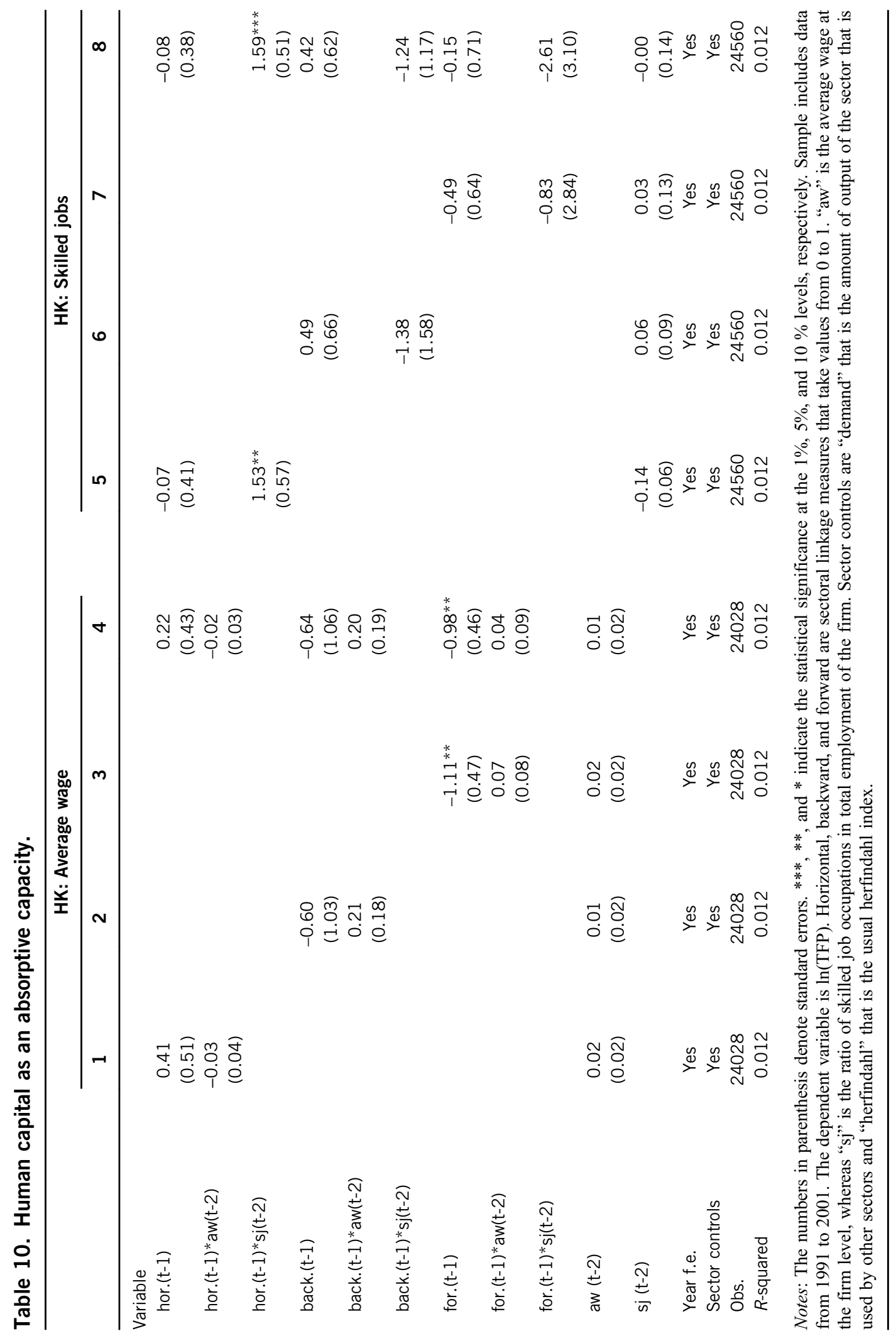


Table 11. Technological closeness as an absorptive capacity.

\begin{tabular}{|c|c|c|c|c|}
\hline & 1 & 2 & 3 & 4 \\
\hline \multicolumn{5}{|l|}{ Variable } \\
\hline \multirow[t]{2}{*}{ hor.(t-1) } & $0.65^{*}$ & & & $0.67 * *$ \\
\hline & $(0.32)$ & & & $(0.32)$ \\
\hline \multirow[t]{2}{*}{ hor. $(\mathrm{t}-1)^{*} \mathrm{tc}(\mathrm{t}-2)$} & $0.18^{* * *}$ & & & $0.22^{* *}$ \\
\hline & $(0.06)$ & & & (0.09) \\
\hline \multirow[t]{2}{*}{ back.(t-1) } & & 0.49 & & 0.75 \\
\hline & & $(1.04)$ & & $(1.02)$ \\
\hline \multirow[t]{2}{*}{ back. $(\mathrm{t}-1)^{*} \mathrm{tc}(\mathrm{t}-2)$} & & -0.09 & & 0.02 \\
\hline & & $(0.28)$ & & $(0.23)$ \\
\hline \multirow[t]{2}{*}{ for.(t-1) } & & & $-1.67^{*}$ & $-1.82^{*}$ \\
\hline & & & $(0.84)$ & $(0.94)$ \\
\hline \multirow[t]{2}{*}{ for. $(\mathrm{t}-1)^{*} \mathrm{tc}(\mathrm{t}-2)$} & & & -0.52 & -0.67 \\
\hline & & & $(0.52)$ & $(0.54)$ \\
\hline \multirow[t]{2}{*}{$\mathrm{tc}(\mathrm{t}-2)$} & $-0.04^{* * *}$ & -0.01 & -0.01 & -0.02 \\
\hline & $(0.01)$ & $(0.01)$ & $(0.02)$ & $(0.02)$ \\
\hline Year f.e. & Yes & Yes & Yes & Yes \\
\hline Sector Controls & Yes & Yes & Yes & Yes \\
\hline Obs. & 21669 & 21669 & 21669 & 21669 \\
\hline R-squared & 0.014 & 0.013 & 0.013 & 0.014 \\
\hline \multicolumn{5}{|c|}{$\begin{array}{l}\text { Notes: The numbers in parenthesis denote standard errors. } * * *, * * \text {, and } * \text { indicate the statistical significance at the } 1 \% \\
5 \% \text {, and } 10 \% \text { levels, respectively. Sample includes data from } 1991 \text { to } 2001 \text {. The dependent variable is } \ln (\mathrm{TFP}) \text {. } \\
\text { Horizontal, backward, and forward are sectoral linkage measures that take values from } 0 \text { to } 1 \text {. "tc" is the technologica } \\
\text { closeness to the industry leader. Sector controls are "demand" that is the amount of output of the sector that is used by } \\
\text { other sectors and "herfindahl" that is the unal herfindahl index }\end{array}$} \\
\hline
\end{tabular}

independent of the skill composition of the local firms. In column (8), we present the full model, i.e., containing interaction terms between all three FDI linkages and absorptive capacity variable. Inclusion of all linkage measures and their interactions do not change the results.

In Table 11 and 12, we repeat the same analysis for other prespecified absorptive capacities, namely technological closeness and export status, respectively. The first column of Table 11 suggests that the closer the domestic firm to the industry leader, the higher the spillovers from horizontal linkage. Moreover, once we control for technological closeness, horizontal channel becomes significant and positive. On the other hand, when the technological closeness is lower, the TFP of the domestic firm is affected negatively, which may capture the competition effect in the sector. These results are consistent with the findings of Kokko, Tansini, and Zejan (1996); Girma and Görg (2005); Girma (2005); and Girma, Greenaway, and Wakelin (2013). As it can be seen from columns (2) to (4), contrary to the case of horizontal linkages, technological closeness does not act as an domestic firm absorptive capacity in the case of vertical linkages.

Table 12 shows that although being an exporter has a significant and positive impact on TFP after two period, the export status does not play a significant role as an absorptive capacity in generating FDI spillovers. In column (3), we observe that negative forward spillovers are realized only by exporters. As discussed above, negative forward spillovers may be realized when the domestic firm is unable to utilize high-quality input produced by MNCs. However, exporters are more productive and employ more skilled employee in our sample suggesting that this is not the source of negative forward spillovers. ${ }^{24}$ Therefore, this result might arise from the fact that exporters are more linked to MNCs by the forward channel than non-exporters. Hence, they might be affected by increased input prices more than non-exporters. If this is the case, then their profits may shrink and hence will their 
Table 12. Export status as an absorptive capacity.

\begin{tabular}{|c|c|c|c|c|}
\hline & 1 & 2 & 3 & 4 \\
\hline \multicolumn{5}{|l|}{ Variable } \\
\hline hor.(t-1) & $\begin{array}{c}0.25 \\
(0.44)\end{array}$ & & & $\begin{array}{c}0.23 \\
(0.43)\end{array}$ \\
\hline hor. $(\mathrm{t}-1)^{*} \exp .(\mathrm{t}-2)$ & $\begin{array}{l}-0.12 \\
(0.13)\end{array}$ & & & $\begin{array}{l}-0.10 \\
(0.14)\end{array}$ \\
\hline back.(t-1) & & $\begin{array}{c}0.24 \\
(0.66)\end{array}$ & & $\begin{array}{c}0.20 \\
(0.65)\end{array}$ \\
\hline back. $(\mathrm{t}-1) * \exp (\mathrm{t}-2)$ & & $\begin{array}{c}0.00 \\
(0.31)\end{array}$ & & $\begin{array}{l}-0.03 \\
(0.31)\end{array}$ \\
\hline for.(t-1) & & & $\begin{array}{l}-0.44 \\
(0.41)\end{array}$ & $\begin{array}{l}-0.46 \\
(0.42)\end{array}$ \\
\hline for. $(\mathrm{t}-1)^{*} \exp (\mathrm{t}-2)$ & & & $\begin{array}{l}-0.63^{*} \\
(0.36)\end{array}$ & $\begin{array}{c}-0.54 \\
(0.40)\end{array}$ \\
\hline exp.(t-2) & $\begin{array}{c}0.04^{*} \\
(0.02)\end{array}$ & $\begin{array}{c}0.03 \\
(0.02)\end{array}$ & $\begin{array}{l}0.05^{* * *} \\
(0.02)\end{array}$ & $\begin{array}{l}0.06^{* * *} \\
(0.03)\end{array}$ \\
\hline Year f.e. & Yes & Yes & Yes & Yes \\
\hline Sector Controls & Yes & Yes & Yes & Yes \\
\hline Obs. & 24582 & 24582 & 24582 & 24582 \\
\hline R-squared & 0.012 & 0.012 & 0.012 & 0.012 \\
\hline \multicolumn{5}{|c|}{$\begin{array}{l}\text { Notes: The numbers in parenthesis denote standard errors. ***, } * * \text {, and } * \text { indicate the statistical } \\
\text { significance at the } 1 \%, 5 \% \text {, and } 10 \% \text { levels, respectively. Sample includes data from } 1991 \text { to } 2001 \text {. The } \\
\text { dependent variable is } \ln (\mathrm{TFP}) \text {. Horizontal, backward, and forward are sectoral linkage measures that } \\
\text { take values from } 0 \text { to } 1 \text {.exp" is the export dummy that takes the value "1" if the firm exports and "0" } \\
\text { otherwise. Sector controls are "demand" that is the amount of output of the sector that is used by other } \\
\text { sectors and "herfindahl" that is the usual herfindahl index. }\end{array}$} \\
\hline
\end{tabular}

Table 13. Export status-split sample analysis.

\begin{tabular}{|c|c|c|c|c|c|c|c|c|}
\hline & \multicolumn{4}{|c|}{ Exporter } & \multicolumn{4}{|c|}{ Non-exporter } \\
\hline & 1 & 2 & 3 & 4 & 5 & 6 & 7 & 8 \\
\hline \multicolumn{9}{|l|}{ Variable } \\
\hline horizontal(t-1) & $\begin{array}{c}0.33 \\
(0.33)\end{array}$ & & & $\begin{array}{c}0.31 \\
(0.32)\end{array}$ & $\begin{array}{c}-0.50 \\
(0.68)\end{array}$ & & & $\begin{array}{c}-0.50 \\
(0.69)\end{array}$ \\
\hline backward(t-1) & & $\begin{array}{c}0.71 \\
(0.47)\end{array}$ & & $\begin{array}{c}0.54 \\
(0.46)\end{array}$ & & $\begin{array}{c}0.14 \\
(1.08)\end{array}$ & & $\begin{array}{c}0.16 \\
(1.10)\end{array}$ \\
\hline forward(t-1) & & & $\begin{array}{l}-1.21^{* * *} \\
(0.37)\end{array}$ & $\begin{array}{l}-1.67^{* * *} \\
(0.38)\end{array}$ & & & $\begin{array}{c}0.14 \\
(0.57)\end{array}$ & $\begin{array}{c}0.15 \\
(0.54)\end{array}$ \\
\hline Year f.e. & Yes & Yes & Yes & Yes & Yes & Yes & Yes & Yes \\
\hline Sector Controls & Yes & Yes & Yes & Yes & Yes & Yes & Yes & Yes \\
\hline Obs. & 16641 & 16641 & 16641 & 16641 & 12877 & 12877 & 12877 & 12877 \\
\hline R-squared & 0.010 & 0.010 & 0.010 & 0.010 & 0.023 & 0.023 & 0.023 & 0.023 \\
\hline \multicolumn{9}{|c|}{$\begin{array}{l}\text { Notes: The numbers in parenthesis denote standard errors. } * * *, * * \text { and } * \text { indicate the statistical significance at the } 1 \% \\
5 \% \text {, and } 10 \% \text { levels, respectively. Sample includes data from } 1991 \text { to } 2001 \text {. The dependent variable is } \ln (\mathrm{TFP}) \text {. } \\
\text { Horizontal, backward, and forward are sectoral linkage measures that take values from } 0 \text { to } 1 \text {. Sector controls are } \\
\text { "demand" that is the amount of output of the sector that is used by other sectors and "herfindahl" that is the usual } \\
\text { herfindahl index. The sample is divided between exporters and non-exporters. Firms with no export experience are } \\
\text { considered as non-exporters. }\end{array}$} \\
\hline
\end{tabular}


productivity. However, due to data limitations, we are unable to formally test this hypothesis in any further detail, and it is out of the scope of this article.

In Table 13 we examine the robustness of our results for export status by splitting the sample into exporters and non-exporters. ${ }^{25}$ The results are consistent with Table 12. Export status does not play a role as an absorptive capacity via backward and horizontal channels, and once again we observe that negative forward spillovers are realized only by exporters.

\section{Other Robustness Checks}

We also run other robustness checks that we do not report in the article due to limited space. First, we test whether the role of human capital as an absorptive capacity is still important for the realization of horizontal spillovers when we control for the technological closeness and export status of the firm in the same regression. The results suggest that human capital and technological closeness form two separate absorptive capacities and both individually play an important role in ensuring positive horizontal spillovers for domestic firms.

Second, following Damijan et al. (2013) we also run the models for subsamples of firms regarding size and the technology gap, which also captures the productivity of the firms. The size sub-samples were classified as small firms (sized 25-50), medium firms (sized 51-100), and large firms (sized above 100). The technology gap sub-samples are classified as technologically faraway firms (the lowest 33.3 percentile of the data), technologically moderately distant (firms with 33-66 percentile of the data), and technologically close firms (those that are in the highest 33.3 percentile of the data). Results in all sub-samples point to the human capital being relevant only for the materialization of horizontal linkages and, therefore reiterating our main finding that human capital matters only for horizontal and not for vertical spillovers to occur. The analysis at the sub-sample level also provides additional information that human capital actually matters the most for small firms and for technologically moderately distant firms.

\section{Conclusion}

Previous studies in the literature have almost come to a consensus that while benefits from horizontal linkages are elusive, backward linkages mostly generate benefits and forward linkages might even hurt the local firms. This finding lends itself as support to policies that would attract FDI that creates a lot of backward linkages with limited forward and horizontal linkages. However, recent findings in the literature have highlighted the fact that these findings can change when absorptive capacities of domestic firms are taken into account. This study aims to contribute to this strand of literature. First of all, we test the role of three different firm-level characteristics as an absorptive capacity in enhancing spillovers from FDI, namely the technological closeness, human capital, and export status. The results suggest that the closer the domestic firm to the industry leader or the higher the human capital, the higher the TFP spillovers from MNCs' presence in the same industry. Export status of domestic firms, on the other hand, does not have a role in generating spillovers from FDI. These results hold strong even after controlling for possible sources of endogeneity as well as other absorptive capacities, suggesting a separate role for each absorptive capacity indicator.

While these findings complement former findings in the literature, they provide a value added to the discussion by proposing an alternative measure of human capital as an absorptive capacity, especially relevant for countries with labor market imperfections. We test the role of two different human capital measures as an absorptive capacity, i.e., average wages and the ratio of skilled jobs in total job offerings of a firm, and find that only the ratio of skilled jobs serves as an absorptive capacity. This finding confirms our hypothesis that the ratio of skilled jobs is a better proxy for human capital compared to average wages, in emerging markets like Turkey with labor market imperfections.

The results of this study are not specific to Turkey. The same result can be generalized to other emerging markets with labor market imperfections. Moreover, with information on both workers' 
education level and their position in the firm, one can compare the effectiveness of our alternative human capital measure with education level of the workers. This cannot be accomplished with our data set as such information is not available. However, an appropriate employer-employee matched data set may allow for such an extension, a task for future research.

\section{Acknowledgments}

This research was conducted while both researchers were affiliated with Bilkent University. We are grateful to Beata Smarzynska Javorcik, Holger Görg, participants of COST Workshop, University of Edinburgh, Joint Workshop of ESRC-ITU and GEP, University of Nottingham, Society for Economic Dynamics, Istanbul, ACES Annual Meeting 2012, Workshop on Multinational Firms, Trade and Innovation, NUI Maynooth, Bilkent University Macroeconomics Study Group, and our reviewers for their very useful and constructive comments and suggestions.

\section{Notes}

1. See Gorg and Strobl (2001), Meyer and Sinani (2009), Wooster and Diebel (2010), Havranek and Irsova (2011), and Havranek and Irsova (2013) for meta-analyses that report overall findings about FDI spillovers.

2. The earlier studies focusing solely on the horizontal spillover channels start with industry-level analyses. These studies mostly point to a positive correlation between FDI presence and average value added per worker (Caves (1974), Mansfield and Romeo (1980), Blomström and Persson (1983), Blomstrom (1986), and Blomstrom and Wolff (1994)). The positive correlation in these studies may arise from the reverse causality problem. To overcome this problem, the case-level studies regarding the spillovers from a specific MNC to firms in the sector MNC operates in were undertaken by Larrain, Lopez-Calva, and Rodriguez-Clare (2000), among others. The problem with these case-level studies is that their findings are specific to the multinational they focus on. Therefore, the results of these studies are limited in providing a general result on FDI spillovers. Hence, the literature moved toward firm-level panel data studies. These include the studies Haddad and Harrison (1993), Harrison and Aitken (1999), Blomström and Sjöholm (1999), Djankov and Hoekman (2000), Konings (2001) on developing economies and Haskel, Pereira, and Slaughter (2007) and Keller and Yeaple (2003) on developed economies.

3. See Schoors and Tol (2002), Jabbour and Mucchielli (2004), Kugler (2006), Sasidharan and Ramanathan (2007), and Blalock and Gertler (2008).

4. For a broader definition of absorptive capacity, see Zahra and George (2002).

5. There are other measures used as an absorptive capacity. For example, Kinoshita (2001) shows that local firms that are R\&D intensive realize positive spillovers from FDI in the Czech Republic.

6. See Blomstrom and Kokko (1998) for a discussion of the channels through which domestic firms benefit from horizontal spillovers.

7. Country-level macro studies have already identified the country-level human capital as critical for ensuring positive growth effects from FDI (see Borensztein, De Gregorio, and Lee (1998), and Xu (2000) among others).

8. While the data has been collected for 2003-2012, the change in the sampling technique makes the recently collected data incompatible with the earlier panel data. Moreover, in this new data set, there is no information on the job composition of labor.

9. In order to calculate the productivity of the firms, one needs to calculate the capital stock for individual firms. Although the time period of this analysis is 1991-2001, the capital stock series is constructed from 1980 in order to reduce problems arising from the initial capital stock calculation.

10. For example, Javorcik (2004) studies the period 1996-2000, Taymaz and Yilmaz (2008) study the period 1990-1996, and Blalock and Gertler (2009) and Blalock and Simon (2009) analyze the period 1988-1996.

11. Because of two problems encountered in the calculation of this capital stock series, firms that have 10-24 employees are excluded from the analysis. First, detailed investment series needed for capital stock calculation is only available after 1991 for the firms that have 10-24 employees. Second, for these firms, the fuel consumption is included in material inputs and cannot be extracted. Furthermore, these problems also prevail with the consistency of the data for firms with less than 10 employees, which are excluded from the analysis.

12. The sectors with the highest foreign presence are other chemicals (352), electrical machinery (383), and transport equipment (384). The sectors with the lowest foreign presence are leather products (323), footwear (324), and furniture (332). The sectors that have the highest production and employment figures are other chemicals (352), ceramics (361), glass (362), electrical machinery (383), and transport equipment (384). The most capital-intensive sectors are beverages (313), textiles (342), other chemicals (352), glass (362), and 
fabricated metals (381). Finally, the highest total factor productivity is observed in the miscellaneous food (321), wood products (322), other chemicals (352), other chemicals (355), other chemicals (356), other chemicals (371), and fabricated metals (381).

13. The calculations can be found in the Appendix.

14. The average of horizontal linkage over the years $1990-2001$ is $10.3 \%$. This average is close to what Taymaz and Y1lmaz (2008) find for the period 1990-1996; however, this is much lower than what Javorcik (2004) finds for Lithuania over the period 1996-2001. The average of backward linkages is 3.9\% in this study, which is close to what Javorcik (2004) and Taymaz and Yilmaz (2008) find for Lithuania and Turkey, respectively. Finally, the forward linkage measure's average is 3.8\%, which is also close to the average that Taymaz and Y1lmaz (2008) find for Turkey, but lower than what Javorcik (2004) finds for Lithuania.

15. Alternatively, we also defined the gap with respect to the average productivity of the top 10 percentile of the firms. Results are robust, and hence the remainder of the results are reported for TC defined with respect to the industry leader.

16. We also run a robustness check with creating two alternative definition of "exporter": two- and three-year exporters.

17. Because of space limitations, the details of these regressions are not provided but are available upon request.

18. Standard errors are clustered at the aggregation of the linkage measure, which is at the industry level. Firms do not usually change their location, and hence we only include firm and time fixed effects and no regional fixed effects.

19. We repeat the whole exercise by instead defining the $\mathrm{ABC}$ measure contemporaneously. The results remain qualitatively robust.

20. In Blalock and Gertler (2009) and Blalock and Simon (2009), the data for human capital only represents information for the years 1995-1996 for spillovers over 1988-1996 period, as is usually the case with education indicators. Having a time continuous annual indicator allows us to take into account the lag structure for both economic and statistical concerns.

21. Because of lack of information on the educational attainment of workers, we are unable to test an exact comparison with the results of Blalock and Gertler (2009).

22. To make sure the interactive terms of the linkage indicators with the human capital measure do not proxy for nonlinearities in the human capital measure itself (in the form of diminishing returns from human capital), we also include the squared value of human capital in our regressions. The results suggest that the nonlinearity is not in the extent of human capital itself but rather it is that the human capital of the domestic firm creates a capacity for the domestic firm to absorb the productivity spillovers from the foreign firms operating in the same sector.

23. As mentioned above, the results in column (4) could be ridden by endogeneity concerns. For example, sectors that are expected to have high productivity growth might attract more FDI due to this characteristic. Controlling for sector-specific characteristics, such as demand or the herfindahl index, might be insufficient in controlling for this phenomenon. When we include the sector-year fixed effects, interaction of human capital with horizontal variable remains positive and significant.

24. We test and find that exporters are more productive and/or employ more skilled employee than nonexporters.

25. Here, to be consistent with Table 12, we take firms that export at least 1 year as exporters. However, we also check the robustness of the results by splitting sample by taking firms with at least 2- or 3-year experience in exporting as the exporters and find that results remain the same.

$26.41 \%$ of the data on investment is composed of zero observations.

27. To ensure robustness of results, the following analysis is replicated using alternative TFP measures; namely residual TFP calculations based on constant shares of factors, OLS estimation based TFP, OP estimation based TFP, and LP estimation based TFP. The main results of the analysis remain qualitatively robust across these alternative productivity measures. However, given the concerns regarding OLS estimation as well as OP estimation in this case, we opt to report the results based on LP in the remainder of the article.

28. In this study, linkages are measured in the traditional approach. Vacek (2010) and Taymaz and Yilmaz (2008) provide alternative product based linkage measures, whereas Barrios et al. (2011) suggest using the inputoutput matrices of the investing country rather than the host country. These alternative measures are not preferred for comparability of findings to the existing and broad literature.

29. The correlation between the relevant coefficients from the three I-O tables are statistically significant at $1 \%$, suggesting a rather slow technological change during the sample in analysis, rendering the use of the same I-O coefficients across different years a plausible assumption.

The backward linkage variable that measures the relationship between domestic and foreign firms when the domestic firm is the input supplier to the foreign firm is calculated as: 


$$
B_{j t}=\sum_{j \neq m} \alpha_{j m} H_{m t}
$$

where $\alpha_{j m}$ is the share of sector $j$ 's output supplied to sector $m$ in total output of sector $j$.

The forward linkage variable that measures the relationship between domestic and foreign firms when the domestic firm purchases inputs from the foreign firm is calculated as:

$$
F_{j t}=\sum_{j \neq m} \sigma_{j m} H_{m t}
$$

where $\sigma_{j m}$ is the share material inputs purchased by sector $j$ from sector $m$ in total inputs purchased by sector $j$.

Hence, $B_{j t}$ measures the foreign presence in the industries that purchases inputs from sector $j$. On the other hand, $F_{j t}$ measures the foreign presence in the industries that sell inputs to sector $j$. Note that inputs supplied in the same sector are not included in the formula since they are measured in $H_{j t}$.

\section{References}

Albrecht, J., and S. Vroman. 2002. A matching model with endogenous skill requirements. International Economic Review 43 (1):283-305. doi:10.1111/iere.2002.43.issue-1.

Arnold, J. M. 2005. Productivity estimation at the plant level: A practical guide. Note.

Barrios, S., H. Gorg, and E. Strobl. 2011. Spillovers through backward linkages from multinationals: Measurement matters! European Economic Review 55 (6):862-75.

Barrios, S., and E. Strobl. 2002. Foreign direct investment and productivity spillovers: Evidence from the Spanish experience. Weltwirtschaftliches Archiv 138 (3):459-81. doi:10.1007/BF02707949.

Blalock, G., and P. J. Gertler. 2008. Welfare gains from foreign direct investment through technology transfer to local suppliers. Journal of International Economics 74 (2):402-21. doi:10.1016/j.jinteco.2007.05.011.

Blalock, G., and P. J. Gertler. 2009. How firm capabilities affect who benefits from foreign technology? Journal of Development Economics 90 (2):192-99. doi:10.1016/j.jdeveco.2008.11.011.

Blalock, G., and D. H. Simon. 2009. Do all firms benefit equally from downstream FDI?: The moderating effect of local suppliers capabilities on productivity gains. Journal of International Business Studies 40 (7):1095-112. doi:10.1057/ jibs.2009.21.

Blomstrom, M., and E. N. Wolff, 1994. Multinational corporations and productivity convergence in Mexico. Working Paper 3141. Cambridge, MA: National Bureau of Economic Research.

Blomstrom, M. 1986. Foreign investment and productive efficiency: The case of Mexico. The Journal of Industrial Economics 35 (1):97-110. doi:10.2307/2098609.

Blomstrom, M., and A. Kokko. 1998. Multinational corporations and spillovers. Journal of Economic Sur-Veys 12 (3):247-77. doi:10.1111/1467-6419.00056.

Blomström, M., and H. Persson. 1983. Foreign investment and spillover efficiency in an underdeveloped economy: Evidence from the Mexican manufacturing industry. World Development 11 (6):493-501. doi:10.1016/0305-750X(83)90016-5.

Blomström, M., and F. Sjöholm. 1999. Technology transfer and spillovers: Does local participation with multinationals matter? European Economic Review 43 (4-6):915-23. doi:10.1016/S0014-2921(98)00104-4.

Borensztein, E., J. De Gregorio, and J.-W. Lee. 1998. How does foreign direct investment affect economic growth? Journal of International Economics 45 (1):115-35. doi:10.1016/S0022-1996(97)00033-0.

Castellani, D., and A. Zanfei. 2003. Technology gaps, absorptive capacity and the impact of inward in- vestments on productivity of European firms. Economics of Innovation and New Technology 12 (6):555-76. doi:10.1080/714933761.

Caves, R. E. 1974. Multinational firms, competition, and productivity in host-country markets. Eco- Nomica 41 (162):176-93.

CEDEFOP, 2012. Skill mismatch: The role of the enterprise. European Centre for the Development of Vocational Training Research Paper 21. Luxembourg: CEDEFOP.

Chang, S. J., and D. Xu. 2008. Spillovers and competition among foreign and local firms in china. Strategic Management Journal 29 (5):495-518. doi:10.1002/(ISSN)1097-0266.

Cohen, W. M., and D. A. Levinthal. 1990. Absorptive capacity: A new perspective on learning and innovation. Administrative Science Quarterly 35 (1):128-52. doi:10.2307/2393553.

Cosar, A. K. 2011. Human capital, technology adoption and development. The B.E. Journal of Macroeconomics 11 (1, March):1-41. doi:10.2202/1935-1690.1907.

Damijan, J. P., M. Rojec, B. Majcen, and M. Knell. 2013. Impact of firm heterogeneity on direct and spillover effects of FDI: Micro-evidence from ten transition countries. Journal of Comparative Eco- Nomics 41:895-922. (forthcoming). doi:10.1016/ j.jce.2012.12.001

Djankov, S., and B. Hoekman. 2000. Foreign investment and productivity growth in Czech enterprises. The World Bank Economic Review 14 (1):49-64. doi:10.1093/wber/14.1.49.

Farole, T., and D. Winkler. 2015, April. The role of foreign firm characteristics, absorptive capacity and the institutional framework for FDI spillovers. Journal of Banking and Financial Economics 1 (3):77-112.

Filiztekin, A., 2011. Education-occupation mismatch in Turkish labor market. Working Paper 35123, University Library of Munich, Munich, Germany. 
Fons-Rosen, C., S. Kalemli-Ozcan, B. E. Srensen, C. Villegas-Sanchez, and V. Volosovych. 2013, March. Quantifying productivity gains from foreign investment. NBER Working Papers 18920. Cambridge, MA: National Bureau of Economic Research.

Girma, S. 2005. Absorptive capacity and productivity spillovers from FDI: A threshold regression analysis. Oxford Bulletin of Economics and Statistics 67 (3):281-306. doi:10.1111/obes.2005.67.issue-3.

Girma, S., and H. Görg. 2005. Foreign direct investment, spillovers and absorptive capacity: Evidence from quantile regressions. Kiel Working Papers 1248. Kiel: Kiel Institute for the World Economy.

Girma, S., H. Görg, and M. Pisu. 2008. Exporting, linkages and productivity spillovers from foreign direct investment. Canadian Journal of Economics/Revue Canadienne D'économique 41 (1):320-40. doi:10.1111/j.1365-2966.2008.00465.x.

Girma, S., D. Greenaway, and K. Wakelin. 2013. Who benefits from foreign direct investment in the UK? Scottish Journal of Political Economy 60 (5, November):560-74. doi:10.1111/sjpe.2013.60.issue-5.

Godart, O., and H. Görg. 2013. Suppliers of multinationals and the forced linkage effect: Evidence from firm level data. Journal of Economic Behavior \& Organization 94 (C):393-404.

Gorg, H., and E. Strobl. 2001. Multinational companies and productivity spillovers: A meta- analysis. Economic Journal 111 (475, November):723-39. doi:10.1111/ecoj.2001.111.issue-475.

Gorodnichenko, Y., J. Svejnar, and K. Terrell. 2007. When does FDI have positive spillovers? Evidence from 17 emerging market economies. CEPR Discussion Papers 6546, CEPR Discussion Papers. London: Centre for Economic Policy Research.

Griliches, Z., and J. Mairesse. 1997. Production functions: The search for identification. Working Papers 97-30, Centre de Recherche en Economie et Statistique.

Groot, W., M. Van, and H. Den Brink. 2000. Overeducation in the labor market: A meta-analysis. Economics of Education Review 19 (2):149-58. doi:10.1016/S0272-7757(99)00057-6.

Haddad, M., and A. Harrison. 1993. Are there positive spillovers from direct foreign investment?: Evidence from panel data for Morocco. Journal of Development Economics 42 (1):51-74. doi:10.1016/0304-3878(93)90072-U.

Harrison, A. E., and B. J. Aitken. 1999. Do domestic firms benefit from direct foreign investment? Evidence from Venezuela. American Economic Review 89 (3):605-18. doi:10.1257/aer.89.3.605.

Haskel, J. E., S. C. Pereira, and M. J. Slaughter. 2007. Does inward foreign direct investment boost the productivity of domestic firms? The Review of Economics and Statistics 89 (3):482-96. doi:10.1162/rest.89.3.482.

Havranek, T., and Z. Irsova. 2011. Estimating vertical spillovers from FDI: Why results vary and what the true effect is. Journal of International Economics 85 (2):234-44. doi:10.1016/j.jinteco.2011.07.004.

Havranek, T., and Z. Irsova. 2013. Determinants of horizontal spillovers from FDI: Evidence from a large meta-analysis. World Development 42 (C):1-15. doi:10.1016/j.worlddev.2012.07.001.

Jabbour, L., and J.-L. Mucchielli. 2004. Technology transfer through backward linkages: The case of the Spanish manufacturing industry. Cahiers de la Maison des Sciences Economiques bla04073. Universit Panthon-Sorbonne (Paris 1).

Javorcik, B. S. 2004. Does foreign direct investment increase the productivity of domestic firms? in search of spillovers through backward linkages. American Economic Review 94 (3):605-27. doi:10.1257/0002828041464605.

Keller, W., and S. R. Yeaple. 2003. Multinational enterprises, international trade and productivity growth: Firm-level evidence from the US. CEPR Discussion Papers 3805, CEPR Discussion Papers. London: Centre for Economic Policy Research.

Kiker, B. F., M. C. Santos, and M. M. De Oliveira. 1997. Overeducation and undereducation: Evidence for Portugal. Economics of Education Review 16 (2):111-25. doi:10.1016/S0272-7757(96)00040-4.

Kinoshita, Y. 2001. R\&d and technology spillovers through FDI: Innovation and absorptive capacity. CEPR Discussion Papers 2775, CEPR Discussion Papers. London: Centre for Economic Policy Research.

Kokko, A., R. Tansini, and M. C. Zejan. 1996. Local technological capability and productivity spillovers from FDI in the Uruguayan manufacturing sector. The Journal of Development Studies 32 (4):602-11. doi:10.1080/00220389608422430.

Konings, J. 2001. The effects of foreign direct investment on domestic firms. The Economics of Transition 9 (3):619-33. doi:10.1111/1468-0351.00091.

Kugler, M. 2006. Spillovers from foreign direct investment: Within or between industries? Journal of Development Economics 80 (2, August):444-77. doi:10.1016/j.jdeveco.2005.03.002.

Larrain, F., L. F. Lopez-Calva, and A. Rodriguez-Clare. 2000. Intel: A case study of foreign direct investment in Central America. CID Working Paper 58, Center for International Development at Harvard University.

Levinsohn, J., and A. Petrin. 2003. Estimating production functions using inputs to control for unobservables. Review of Economic Studies 70 (2):317-41. doi:10.1111/roes.2003.70.issue-2.

Liu, Z. 2008. Foreign direct investment and technology spillovers: Theory and evidence. Journal of Development Economics 85 (1-2):176-93. doi:10.1016/j.jdeveco.2006.07.001.

Mansfield, E., and A. Romeo. 1980. Technology transfer to overseas subsidiaries by U.S.-based firms. The Quarterly Journal of Economics 95 (4):737-50. doi:10.2307/1885489.

Meyer, K. E., and E. Sinani. 2009. When and where does foreign direct investment generate positive spillovers? A meta-analysis. Journal of International Business Studies 40 (7):1075-94. doi:10.1057/jibs.2008.111.

Olley, G. S., and A. Pakes. 1996. The dynamics of productivity in the telecommunications equipment industry. Econometrica 64 (6):1263-97.

Quinn, M. A., and S. Rubb. 2006. Mexico's labor market: The importance of education-occupation matching on wages and productivity in developing countries. Economics of Education Review 25 (2):147-56. doi:10.1016/j.econedurev.2005.01.003.

Sasidharan, S., and A. Ramanathan. 2007. Foreign direct investment and spillovers: Evidence from Indian manufacturing. International Journal of Trade and Global Markets 1 (1):5-22. doi:10.1504/IJTGM.2007.015573.

Saygilı, S., C. Cihan, C. Yalcin, and T. Hamsici. 2010. Turkiye imalat sanayiin ithalat yapısı. Working Papers 1002, Research and Monetary Policy Department, Central Bank of the Republic of Turkey. 
Schoors, K., and B. V. D. Tol. 2002. Foreign direct investment spillovers within and between sectors: Evidence from Hungarian data. Working Papers of Faculty of Economics and Business Administration, Ghent University, Belgium 02/157, Ghent University, Faculty of Economics and Business Administration.

Taymaz, E., and K. Yilmaz. 2008. Foreign direct investment and productivity spillovers. Working paper.

Vacek, P. 2010. Panel data evidence on productivity spillovers from foreign direct investment: Firm-level measures of backward and forward linkages. Working Papers IES 2010/19, Charles University Prague, Faculty of Social Sciences, Institute of Economic Studies.

Wooster, R. B., and D. S. Diebel. 08 2010. Productivity spillovers from foreign direct investment in developing countries: A meta-regression analysis. Review of Development Economics 14 (s1):640-55. doi:10.1111/j.1467-9361.2010.00579.x.

$\mathrm{Xu}$, B. 2000. Multinational enterprises, technology diffusion, and host country productivity growth. Journal of Development Economics 62 (2):477-93. doi:10.1016/S0304-3878(00)00093-6.

Zahra, S. A., and G. George. 2002. Absorptive capacity: A review, reconceptualization, and extension. The Academy of Management Review 27 (2):185-203.

Zhang, Y., H. Li, Y. Li, and L.-A. Zhou. 2010. Fdi spillovers in an emerging market: The role of foreign firms' country origin and domestic firms' absorptive capacity. Strategic Management Journal 31:495-518.

\section{Appendix: Online Data}

\section{Total Factor Productivity (TFP)}

In order to calculate the TFP, we need a measure of output, material inputs, labor, capital stock, and energy. We next detail the definitions and when relevant the calculation of these variables of interest. All variables are measured in 1990 Turkish Liras and are obtained from TurkStat.

Output is measured as the sum of the revenues from the annual sales of the firm's final products, the revenues from the contract manufacturing, and the value of stock of final products at the end of the year minus the value of stock of final products at the beginning of the year, deflated by the relevant three-digit output price deflator.

Material inputs are measured as the sum of the value of purchases of intermediate inputs (except for the fuel) and the value of stock of material inputs at the beginning of the year minus the value of stock of material inputs at the end of the year. This variable is deflated by the relevant three-digit input price deflator.

Energy variable is the sum of the values of fuel purchases and electricity used in production. Electricity used in the production is calculated as the sum of the value of electricity purchased and the value of electricity produced minus the value of electricity sold. Both electricity and fuel are deflated by their own price deflators.

Labor is measured as the number of employees of the firm in a given year. Also, skill disaggregation of labor is available from the data. The employees that work in production are classified as technical personnel, foremen, and workers. Furthermore, technical personnel are disaggregated into middle- and high-level technical personnel. The employees that work in management are classified as management employees, office employees, and other type of employees.

Firm-level data on investment in machinery and equipment, building and structure, transportation equipment, and computer and programming are available. Except for computer and programming, all series are available since 1983. Computer and programming investment is reported since 1995. Since the disaggregated investment deflator is not available, the different investment series are deflated by the aggregate investment deflator. The aggregate investment deflator is gathered from Saygili et al. (2010).

Using these investment series, capital stock series for machinery and equipment, building and structure, transportation equipment and computer and programming are constructed applying the perpetual inventory method. Following Taymaz and Yilmaz (2008), depreciation rates of 5\%, 10\%, $20 \%$ and $30 \%$ are used for building and structure, machinery and equipment, transportation equipment, computer and programming respectively, to construct initial capital stock and to apply the perpetual inventory method.

For the firms that report zero investment at their initial year, it is assumed that they can't be producing without capital. Therefore, the initial capital stock is calculated at the year that they report 
positive investment, and this amount is iterated back to the beginning year by dividing capital stock $(1-\delta)$ each year.

After calculating capital stock series for building and structure, machinery and equipment, transportation equipment, computer and programming, these series are aggregated to form the total capital stock series of the firm.

The TFP for each firm is calculated using the Levinsohn-Petrin methodology. Earlier studies have used OLS estimation of the production function to calculate the TFP. However, as suggested by Griliches and Mairesse (1997), treating inputs of production as exogenous variables can create biases in the OLS estimation of the TFP. Another problem with the OLS estimation of the production function is the selection bias. The selection bias is due to the fact that the capital stock, as a state variable, responds to productivity shocks with a lag. If a firm possesses large amounts of capital stock, it will expect higher returns for a given level of productivity and, therefore, it will continue to operate in the market even if it observes low levels of productivity for the next period (Olley and Pakes 1996). On the contrary, firms with lower levels of capital may not be able to remain in the market in similar conditions. Hence, the resulting capital coefficient is an underestimate of the true coefficient.

Olley and Pakes (1996) (OP, henceforth) and Levinsohn and Petrin (2003) (LP, henceforth) have proposed ways of resolving these two biases. In this study, the LP estimation procedure is used due to large number of zero observations in investment series in the Turkish manufacturing industry dataset. ${ }^{26}$ We could have used OP by using only positive investment observations in order to avoid the nonmonotonicity problem. However, this causes a significant loss of observations and, hence, efficiency. ${ }^{27}$

In estimating the TFP using the LP methodology we use value added as the dependent variable rather than output. As discussed by Arnold (2005), LP is not able to identify the coefficients for material inputs, energy, labor, and capital due to the lack of variation in data when output is used as the dependent variable. We find that this is also the case for the Turkish manufacturing industry. Therefore, we use value added defined as the gross output net of intermediate inputs, as the dependent variable. Given our focus on identifying the differential role played by skilled and unskilled labor in spillovers, we take the skill composition of the firms into account in estimating the TFP, by separately including jobs that require skills and those that do not require skills in the analysis.

\section{Linkage Measures}

We next discuss the calculation of the FDI indicators, namely the horizontal, forward, and backward linkages. ${ }^{28}$ This calculation requires the input-output matrix of three-digit industries. The input-output matrix is only available for the years 1990, 1996, and 1998. We use the 1990 matrix for the years 1990-1993, the 1996 matrix for the years 1994-1997, and the 1998 matrix for the years 1998-2001. ${ }^{29}$ The horizontal linkage that measures the relationship between domestic and foreign firms when they operate in the same sector is calculated as:

$$
H_{j t}=\sum_{m \varepsilon j}\left(f_{m t}{ }^{*} Q_{m t}\right) / \sum_{m \varepsilon j} Q_{m t}
$$

where $f_{m t}$ is the foreign-ownership share of plant $m$ at time $t, Q_{m t}$ is the output of plant $m$ at $t$. Therefore, $H_{j t}$ can be defined as the share of the foreign affiliated plants' output in sector $j$ in the total output of sector $j$. Note that, $H_{j t}$ increases when there is an increase in foreign investment in sector $j$ or an increase in the output of foreign-affiliated plants in sector $j$. 